Wulanda, et al/Jurnal Ekonomi Syariah Teori dan Terapan Vol. 6 No. 8 Agustus 2019: 1690-1705; PERAN LMI DALAM PEMBERDAYAAN EKONOMI MASYARAKAT MISKIN MELALUI PROGRAM GADUH TERNAK BAROKAH DI KABUPATEN TRENGGALEK

\title{
PERAN LMI DALAM PEMBERDAYAAN EKONOMI MASYARAKAT MISKIN MELALUI PROGRAM GADUH TERNAK BAROKAH DI KABUPATEN TRENGGALEK ${ }^{1}$
}

\author{
Diah Ayu Wulanda \\ Departemen Ekonomi Syariah - Fakultas Ekonomi dan Bisnis - Universitas Airlangga \\ Email: diahayuww94@gmail.com \\ Siti Inayatul Faizah \\ Departemen Ekonomi Syariah - Fakultas Ekonomi dan Bisnis - Universitas Airlangga \\ Email: siti-i-f@feb.unair.ac.id
}

\begin{abstract}
:
Gaduh Ternak Barokah is a program established by the Infaq Management Institute to empower the poor who have the ability to raise livestock to meet their daily needs. This program is a collaboration between breeders and the Infaq Management Institute where capital is provided in the form of livestock, namely goats. Breeders row livestock with their own energy and the ability to raise livestock only and later the results of animal husbandry were divided according to mutual agreement. This Gaduh Ternak Barokahis programmed to the economically disadvantaged society of Banaran, Depok Village, Bendungan suburb, Trenggalek Regency. This research aims at determining the role of Gaduh Ternak Barokah program on alleviating the poor society of Banaran, Depok Village, Bendungan suburb, Trenggalek regency based on prosperity indicators. The research approach is qualitative descriptive and uses a case study strategy. The informants in this study consisted of those who received assistance from the program, namely farmers. The technique of determining informants in this study used purposeive sampling techniques and data collection techniques were carried out through interviews and direct observation. Based on the research result, it is shown that Gaduh Ternak Barokah has a role on improving the farmers' wealth in the point of view of prosperity.
\end{abstract}

Keywords: Role, Empowerment, Farmers, Animal Husbandry Program

\section{PENDAHULUAN}

Rukun Islam merupakan lima tindakan dasar dalam ajaran agama islam yang dianggap sebagai pondasi wajib bagi orang-orang yang beriman dan merupakan dasar bagi kehidupan semua umat muslim yang ada diseluruh dunia ini. Rukun Islam terdiri daripada lima perkara, yaitu:

1. Syahadat: menyatakan kalimat tiada

Tuhan selain Allah, dan Muhammad itu utusan Allah.
2. Shalat: ibadah sembahyang lima waktu sehari.

3. Zakat: memberikan $2,5 \%$ dari uang simpanan kepada orang miskin atau yang membutuhkan.

4. Saum atau Puasa : berpuasa dan mengendalikan diri selama bulan suci Ramadan.

5. Haji: pergi beribadah ke Mekkah, setidaknya sekali seumur hidup bagi mereka yang mampu.

\footnotetext{
${ }^{1}$ Jurnal ini merupakan bagian dari skripsi Diah Ayu Wulanda, NIM: 04151 1433082, yang diuji pada tanggal 25 Juni 2019.
} 
Wulanda, et al/Jurnal Ekonomi Syariah Teori dan Terapan Vol. 6 No. 8 Agustus 2019: 1690-1705; PERAN LMI DALAM PEMBERDAYAAN EKONOMI MASYARAKAT MISKIN MELALUI PROGRAM GADUH TERNAK BAROKAH DI KABUPATEN TRENGGALEK

Dari kelima rukun islam diatas zakat merupakan salah satu kewajiban muslim yang tidak hanya berhubungan dengan Allah semata (habluminnallah) tetapi zakat juga memiliki hubungan degan sesama manusia (habluminannas).

Allah swt telah memerintahkan kepada setiap umat muslim yang memilki harta mencapai nisab untuk mengeluarkan zakat hartanya setiap tahun. la berikan kepada yang berhak menerima dari kalangan fakir serta selain mereka yang zakat boleh diserahkan kepada mereka sebagaimana telah diterangkan dalam Al Qur'an. Di antara manfaat mengeluarkan zakat adalah untuk membantu orang-orang fakir dalam menutupi kebutuhan pokok sehari-hari mereka. Zakat juga memiliki peranan yang sangat strategis dalam upaya pengentasan kemiskinan atau pembangunan ekonomi. Berbeda dengan sumber keuangan untuk pembangunan yang lain, zakat tidak memiliki dampak baik apapun kecuali ridha dan mengharap pahala dari Allah swt semata. Dalam QS At Taubah 9:103 dimana artinya : "ambillah zakat dari sebagian harta mereka, dengan zakat itu kamu membersihkan dan mensucikan mereka dan mendoalah untuk mereka. Sesungguhnya doa kamu itu (menjadi) ketentraman jiwa bagi mereka. Dan Allah Maha mendengan lagi Maha mengetahui".
Namun demikian, bukan berarti mekanisme zakat tidak ada system kontrolnya. Nilai strategis zakat dapat dilihat melalui: Pertama, zakat merupakan panggilan agama. Kedua, sumber kevangan zakat tidak akan pernah berhenti. Artinya orang yang membayar zakat, tidak akan pernah berhenti dan akan terus membayar setiap tahun atau dalam suatu periode waktu yang telah ditentukan sesuai dengan ketetapan. Ketiga, zakat secara empiric dapat menghapus kesenjangan social dan sebaliknya dapat menciptakan restribusi aset dan pemerataan pembangunan. Agar menjadi sumber dana yang dapat dimanfaatkan bagi kesejahteraan masyarakat, terutama untuk mengentaskan kemiskinan dan menghilangkan kesenjangan sosial, maka perlu adanya pengelolaan zakat, infaq dan shadaqah secara professional dan bertanggung jawab yang dilakukan oleh masyarakat bersama Pemerintah, karena selain sebagai bentuk ibadah ritual, zakat juga mencakup dimensi sosial, ekonomi serta merupakan institusi yang akan menjamin terciptanya keadilan ekonomi dan kesejahteraan bagi masyarakat secara keseluruhan. Oleh karena itu, lembaga zakat harus pula didorong untuk dapat menciptakan lapangan usaha produktif bagi kelompok masyarakat yang tidak mampu, Allah menjelaskan tentang zakat 
Wulanda, et al/Jurnal Ekonomi Syariah Teori dan Terapan Vol. 6 No. 8 Agustus 2019: 1690-1705; PERAN LMI DALAM PEMBERDAYAAN EKONOMI MASYARAKAT MISKIN MELALUI PROGRAM GADUH TERNAK BAROKAH DI KABUPATEN TRENGGALEK

pada ayat Al Quran surat At Taubah ayat 60.

Ada delapan orang yang termasuk dalam kelompok yang berhak menerima zakat. Kelompok yang behak menerima zakat yaitu fakir, miskin, amil atau pengurus zakat, mu'allaf, hamba sahaya, gharimin, fisabilillah, dan ibnus sabil. Zakat adalah ibadah yang memiliki peranan penting dalam segi ekonomi, sosial, budaya, serta agama yang berguna untuk mensejahterakan masyarakat. Dengan begitu terlihat jelas seberapa penting zakat berperan dalam kehidupan manusia. Zakat menjadi perwujudan ibadah kepada Allah SWT sekaligus sebagai perwujudan dari rasa kepedulian sosial bagi sesama. Seseorang yang menunaikan zakat dapat mempererat hubungannya dengan Allah SWT maupun hubungannya kepada sesama manusia.

'Menindaklanjuti Keputusan Menteri Agama Nomor 37 Tahun 2003 tentang Pelaksanaan Undang-Undang Nomor 38 Tahun 1999 tentang Pengelolaan Zakat. Lembaga Manajemen Infaq (LMI) adalah lembaga filantropi profesional yang berkhidmat mengangkat harkat martabat masyarakat dhuafa (masyarakat kurang mampu) melalui penghimpunan dana ZISWAF (zakat, infaq, sedekah, dan wakaf) masyarakat dan dana corporate sosial responsibilty perusahaan. LMI didirikan pada September 1995 oleh sejumlah alumnus STAN-Prodip dengan nama Yayasan
Lembaga Infaq Ukhuwah Islamiyah, sejak tahun 2005 menjadi Lembaga Manajemen Infaq (LMI). Pada tahun yang sama di bulan Mei, LMI dilegalkan sebagai LAZ Jawa Timur melalui SK Gubernur No. 451/1702/032/2005. Kini Lembaga Manajemen Infaq (LMI) terus berbenah dan tumbuh berkembang. Sampai saat ini, Lembaga Manajemen Infaq (LMI) memiliki 21 kantor cabang di Jawa Timur, serta memiliki jejaring tingkat Nasional. Salah satu cabang tersebut adalah LMI Trenggalek bertempat di JIn. Supriyadi no. 16 Kabupaten Trenggalek (https://m.facebook.com/lmi.trenggalek).

Penyaluran dana zakat melalui pemberdayaan di bidang ekonomi merupakan salah satu upaya untuk membangun daya (masyarakat) dengan mendorong, memotivasi dan membangkitkan kesadaran akan potensi yang dimilikinya serta berupaya untuk mengembangkannya. Keberdayaan masyarakat adalah unsur dasar yang memungkinkan suatu masyarakat bertahan. Dalam pengertian yang dinamis, yaitu mengembangkan diri dan mencapai kemajuan. Keberdayaan masyarakat menjadi sumber dari apa yang dikenal sebagai Ketahanan Nasional.

Dari sudut pandang sejarahnya, Lembaga Manajemen Infaq (LMI) juga memiliki visi dan misi, sebagai berikut: 
Wulanda, et al/Jurnal Ekonomi Syariah Teori dan Terapan Vol. 6 No. 8 Agustus 2019: 1690-1705; PERAN LMI DALAM PEMBERDAYAAN EKONOMI MASYARAKAT MISKIN MELALUI PROGRAM GADUH TERNAK BAROKAH DI KABUPATEN TRENGGALEK

Visi

Menjadi lembaga dana sosial yang mengakat di Jawa Timur dan berperan di tingkat nasional serta menjadi pelopor dalam menghimpun dan mendayagunakan zakat, infaq, shodaqoh, wakaf, hibah dan dana sosial lainnya untuk pemberdayaan umat.

\section{Misi}

1. Mengarus utamakan zakat, infaq, shodaqoh, wakaf, hibah, dan dana sosial lainnya segabai sumber daya pemberdayaan umat melalui sosialisasi dan pendidikan public

2. Menghimpun zakat, infaq, sodaqoh, wakaf, hibah, dan dana sosial lainnya secara professional, transparan, dan akuntabel

3. Mendayagunakan zakat, infaq, shodaqoh, wakaf, hibah, dan dana sosial lainnya secara tepat sasaran dan mengedepankan kemitraan professional.

Lembaga Manajemen Infaa Trenggalek menyalurkan dana zakat, infaq dan shadaqah. Dimana selain menjadi badan penyalur dana zakat di DSM juga terdapat program yang terdiri dari program kemanusiaan, program pemberdayaan dan dakwah. yang salah satunya berupa program modal hewan ternak bertujuan untuk memfasilitasi masyarakat melalui Pemberdayaan ekonomi untuk mewujudkan kemandirian, dan kesejahteraan hidup yang lebih baik karena penyalurannya bersifat produktif dan disalurkan dalam bentuk bantuan modal berupa hewan ternak yang diberikan Lembaga Manajemen Infaq kepada mustahiq diharapkan dapat mengembangkan usaha dan bisa meningkatkan pendapatan mereka.

Lokasi penelitian berada di Dusun Banaran Desa Depok Kecamatan Bendungan Kabupaten Trenggalek. Merupakan pendistribusian paling banyak untuk pemberdayaan ekonomi khususnya dalam program Gaduh Ternak Barokah LMI Dengan hal tersebut, peneliti tertarik untuk melakukan penelitian pada LMI Trenggalek maka dengan itu, berdasarkan latar belakang diatas, maka penelitian ini diberi judul "Peran LMI Dalam Pemberdayaan Ekonomi Masyarakat Miskin Melalui Program Gaduh Ternak Barokah di kabupaten Trenggalek".

\section{LANDASAN TEORI}

Perilaku individu dalam kesehariannya hidup bermasyarakat berhubungan erat dengan peran. Karena peran mengandung hal dan kewajiban yang harus dijalani seorang individu dalam bermasyarakat. Sebuah peran harus dijalankan sesuai dengan norma-norma yang berlaku juga di masyarakat. Seorang individu akan terlihat status sosialnya hanya dari peran yang dijalankan dalam kesehariannya. 
Wulanda, et al/Jurnal Ekonomi Syariah Teori dan Terapan Vol. 6 No. 8 Agustus 2019: 1690-1705; PERAN LMI DALAM PEMBERDAYAAN EKONOMI MASYARAKAT MISKIN MELALUI PROGRAM GADUH TERNAK BAROKAH DI KABUPATEN TRENGGALEK

Dalam Kamus Bahasa Indonesia (2007:641), peran diartikan sebagai pemain, perangkat tingkah yang diharapkan dimiliki pleh yang berkedudukan di masyarakat.

Menurut Berry dan Suparlan (dalam Soekanto, 1992) peran adalah seperangkat harapan yang dikenakan pada masyarakat yang menempati kedudukan sosial tertentu. Manusia sebagai makhluk sosial memiliki kecenderungan untuk hidup berkelompok. Dalam kehidupan berkelompok tersebut terjadi suatu interaksi antar manusia. Munculnya interaksi diantara mereka menun jukkan bahwa mereka saling ketergatungan satu sama lain. Pada kehidupan suatu masyarakat akan muncuk adanya peran, baik peran perorangan maupun peran kelompok.

Zakat dalam Al-qur'an disebutkan sebanyak 32 dan 82 kali diulang dengan menggunakan istilah yang sinonim dari kata zakat yaitu kata shodaqah dan infaq. Pengulangan tersebut mengandung maksud bahwa zakat mempunyai kedudukan, fungsi dan peran yang sangat penting di dalam slam. Hal ini menunjukkan bahwa islam sangat memperhatikan hubungan manusia dengan tuhan (hablun min Allah) dan hubungan dengan manusia (hablun min al-nas) (Ali, 2006:24).

Menurut Muhammad dan abubakar (2011: 9) zakat adalah "ibadah fardhiyah yang mengukuhkan hubungan Antara seorang muzakki dengan tuhannya. Kata fardhiyah bermakna wajib, maka hokum zakat adalah wajib bagi umat muslim yang sudah memenuhi persyaratan".

Pemberdayaan mengandung arti tangguh atau kuat. Secara etimologis pemberdayaan berasal dari kata daya yang berarti kekuatan atau kemampuan (Sulistiani, 2004:77). Kata lain yang memiliki pengertian sama dengan istilah pemberdayaan adalah pembangunan (development) dan penguasaan (empowerment) (Mahendrawati, 2001:42).

Hadi dalam Rappaport (2004:3) menjelaskan bahwa pemberdayaan adalah suatu cara dimana rakyat, organisasi, dan komunitas diarahkan agar mampu menguasai (atau berkuasa atas) kehidupanya. Pengertian pemberdayaan menurut Hikmat dalam Ardle (2010:14) pemberdayaan sebagai proses pengambilan keputusan oleh orang-orang yang secara konsekuen melaksanakan keputusan tersebut. Definisi pemberdayaan yang dikemukakan diatas dapat ditarik suatu kesimpulan bahwa pemberdayaan merupakan suatu upaya untuk memampukan dan memandirikan masyarakat atau dengan kata lain adalah bagaimana menolong masyarakat untuk mampu menolong dirinya sendiri.

Konsep pemberdayaan dalam wacana pembangunan masyarakat itu sendiri selalu dihubungkan dengan konsep mandiri, partisipasi, jaringan kerja, dan 
Wulanda, et al/Jurnal Ekonomi Syariah Teori dan Terapan Vol. 6 No. 8 Agustus 2019: 1690-1705; PERAN LMI DALAM PEMBERDAYAAN EKONOMI MASYARAKAT MISKIN MELALUI PROGRAM GADUH TERNAK BAROKAH DI KABUPATEN TRENGGALEK

keadilan. Pada dasarnya pemberdayaan diletakkan pada kekuatan tingkat individu dan sosial. Partisipasi merupakan kompenen penting dalam pembangkitan kemandirian dan proses pemberdayaan, sebaiknya orang-orang harus terlibat dalam proses tersebut sehingga mereka dapat lebih memperhatikan hidupnya untuk memperoleh rasa percaya diri, memiliki harga diri dan pengetahuan untuk mengembangkan keahlian baru. Menurut Sumodiningrat (1999:56), konsep pemberdayaan secara ringkas dapat dikemukakan sebagai berikut:

1. Perekonomian rakyat.

2. Perubahan structural

3. Pemberdayaan ekonomi rakyat

Adapun konsep pemberdayaan (Tamkin) dalam perspektif islam yaitu pemberian atau pengalihan sebagian kekuasaan, kekuatan atau kemampuan (power) kepada masyarakat, organisasi atau individu agar menjadi lebih berdaya dan mandiri. Selanjutnya, menekankan pada proses menstimulasi, mendorong dan memotivasi individu agar mempunyai kemampuan atau keberdayaan untuk menentukan apa yang menjadi pilihan hidupnya (Yulizar dan Taufik, 2016:88).

Kata tamkin dalam kamus-kamus bahasa merupakan bentuk mashdar dari fi'il makkana. Kata tersebut memiliki arti yang sama dengan kata amkana. Menurut Ibnu
Darid dalam jamharah al-Lughah dalam Yunizar dan Taufik (2016:76):

"Fulan memiliki makanah diisi penguasa artinya ia memiliki kedudukan"

Dengan demikian kata tamkin menunjukkan atas kemampuan melakukan sesuatu, kekokohan, memiliki kekuatan, kekuasaan, pengaruh dan memiliki kedudukan atau tempat; baik itu bersifat hissi (dapat dirasakan/materi) seperti menetapnya burung dalam sangkarnya atau bisa bersifat ma'nawi seperti kokohnya atau teguhnya orang tersebut disisi penguasaa.Pengertian tersebut dalam bahasa ekonomi bisa diistilahkan dengan pemberdayaan; dimana gambaran tentang pemberdayaan tidak bisa lepas dari kekuasaan individu atau kelompok yang memiliki atau menggunakan kesempatan untuk meraih kekuasaan ke tangan mereka, meredistribusikan kekuasaan dari kaum berpunya kepada kaum yang tidak berpunya dan seterusnya.Pemberdayaan bertujuan untuk meningkatkan keberdayaan dari mereka yang dirugikan.

Islam pada dasarnya adalah agama pemberdayaan. Menurut pandangan Islam, pemberdayaan merupakan gerakan tanpa henti. Hal ini sejalan dengan paradigma Islam sendiri sebagai agama gerakan atau perubahan. Islam juga menekankan pentingnya pemberdayaan masyarakat lemah seperti 
Wulanda, et al/Jurnal Ekonomi Syariah Teori dan Terapan Vol. 6 No. 8 Agustus 2019: 1690-1705; PERAN LMI DALAM PEMBERDAYAAN EKONOMI MASYARAKAT MISKIN MELALUI PROGRAM GADUH TERNAK BAROKAH DI KABUPATEN TRENGGALEK

anak yatim, fakir, dan miskin. Sebagaimana yang telah Allah SWT suratkan di dalam AlQur'an surat Al-Hasyr ayat tujuh. Ayat tersebut menjelaskan bahwa pada zaman Rasulullah SAW Allah telah memerintahkan untuk membagikan harta rampasan yang dimiliki tersebut tidak kepada Rasul saja, melainkan diberikan juga kepaa penduduk, kaum kerabat, anak yatim, orang miskin, dan fisabilillah. Hal ini yang demikian tersebut telah jelas bahwa wajib mendistribusikan dan meratakan pendapatan agar kekayaan tidak terjadi disatu kalangan saja. Hal ini tentu dengan cara memberdayakan ekonomi yang sebanyak-banyaknya hingga kekayaan pun merata. Pengertian lain menjelaskan bahwa pemberdayaan atau pengembangan atau tepatnya pembangunan sumber daya manusia adalah upaya untuk memperluas horizon bagi masyarakat. Ini berarti masyarakat diberdayakan untuk melihat dan memilih sesuatu yang bermanfaat untuk dirinya sendiri. Memakai logika ini, dapat dikatakan bahwa masyarakat yang berdaya adlah yang dapat memilih dan mempunyai kesempatan untuk mengadakan pilihan.

Menurut Machendrawaty (2001:44) ada tiga macam pemberdayaan yang diperjuangkan dalam konteks keumatan masa kini, yakni pemberdayaan dalam tataran ruhaniah, intelektual, dan ekonomi. 1. Pemberdayaan pada matra ruhaniah
Pergeseran nilai masyarakat islam saat ini sangat mengguncang kesadaran Islam. Kepribadian kaum muslim terutama mayoritas generasi mudanya begitu mudah terpengaruh oleh budaya negatif barat yang merupakan berlawanan dari nilai-nilai islam. Hal ini diperparah dengan gagalnya pendidikan agama di hampir semua lini pendidikan.

Agar dapat keluar dari persoalan ini, masyarakat Islam haru berjuang keras untuk melahirkan desain besar kurikulum pendidikan untuk setiap wilayah pendidikan, yang benar-benar berorientasi pada pemberdayaan total ruhaniyah islamiyah yang tidak bertentangan dengan perjuangan kebenaran ilmiah dan kemodernan.

2. Pemberdayaan intelektual

Secara jelas dapat dirasakan umat islam yang ada di Indonesia bahkan di seluruh wilayah sudah tertinggal dalam kemajuan dan penguasan teknologi. Maka diperlukan berbagai upaya pemberdayaan intelektual sebagai sebuah perjuangan besar.

3. Pemberdayaan ekonomi

Masalah kemiskinan menjadi demikian identik dengan masyarakat islam Indonesia. Pemecahannya, adalah tanggung jawab masyarakat islam sendiri, yang selama ini selalu terpinggirkan. Dalam konteks ekonomi, seorang putra islam dan generasi Qur'ani awal terbaik. 
Wulanda, et al/Jurnal Ekonomi Syariah Teori dan Terapan Vol. 6 No. 8 Agustus 2019: 1690-1705; PERAN LMI DALAM PEMBERDAYAAN EKONOMI MASYARAKAT MISKIN MELALUI PROGRAM GADUH TERNAK BAROKAH DI KABUPATEN TRENGGALEK

Situasi ekonomi masyarakat islam Indonesia bukan untuk diratapi, melainkan untuk dicarikan jalan pemecahanya. Upaya yang dapat dilakukan untuk keluar dari permaslahan ekonomi ini, diperlukan perjuangan besar dan komitmen dari setiap kompenen umat. Pribadi muslim ditantang untuk lebih keras dalam bekerja, berkreasi, dan berwirausaha, lebih-lebih dalam bekerja sama, komunikatif dalam berinteraksi, lebih terampil dlam memfalisitasi jaringan kerja, dan lebih professional dalam mengolah potensipotensi dan kekuatan-kekuatan riil ekonomi umat. Agar dapat keluar dari himpitan situasi ekonomi seperti sekarang. Disamping penguasaan terhadap ketrampilan hidup, ketrampilan berwirausaha, dibutuhkan juga pembangunan dan pemberdayaan ekonomi kerakyatan, yang selama ini tidak pernah dilirik.

Setiap manusia memiliki keinginan untuk sejahtera, sejahtera menunjukkan ke suatu keadaan yang serba baik atau suatu kondisi manusia, dimana orang-orang di dalamnya keadaan makmur, sehat, dan damai. Menurut Kamus Bahasa Indonesia, sejahtera juga mengandung pengertian aman sentosa, makmur, serta selamat terlepas dari segala macam gangguan.

Dalam paradigma pembangunan ekonomi, perubahan kesejahteraan masyarakat merupakan bagian yang tidak terpisahkan. Hal ini dikarenakan pembangunan ekonomi dikatakan berhasil jika tingkat kesejahteraan masyarakat semakin baik. Keberhasilan pembangunan ekonomi tanpa menyertakan peningkatan kesejahteraan masyarakat akan mengakibatkan kesenjangan dan ketimpangan dalam kehidupan masyarakat. Kesejahteraan masyarakat adalahsuatu kondisi yang memperlihatkan tentang keadaan kehidupan masyarakat yang dapat dilihat dari standar kehidupan masyarakat. (Badrudin, 2012).

Stiglitz (2011) menyatakan bahwa untuk mendefinisikan kesejahteraan rumusan multidimensi harus digunakan. Dimensi-dimensi tersebut meliputi: standar hidup material (pendapatan, konsumsi, dan kekayaan); (2) kesehatan; (3) pendidikan; (4) aktivitas individu termasuk bekerja; (5) suara politik (data pemerintahan, hubungan dan kekerabatan sosial); (6) lingkungan hidup (kondisi sekarang dan masa depan) baik yang bersifat ekonomi maupun fisik. Semua dimensi ini menunjukkan kualitas hidup masyarakat dan untuk mengukurnya diperlukan data objektif dan subjektif.

Adapun tujuan tersebut untuk memberdayakan dan mengentas kemiskinan yang ada di Indonesia. Kemiskinan seringkali dipahami dalam pengertian yang sangat sederhana, yaitu rendahnya penghasilan, tidak memiliki mata pencaharian yang mapan, dan tidak 
Wulanda, et al/Jurnal Ekonomi Syariah Teori dan Terapan Vol. 6 No. 8 Agustus 2019: 1690-1705; PERAN LMI DALAM PEMBERDAYAAN EKONOMI MASYARAKAT MISKIN MELALUI PROGRAM GADUH TERNAK BAROKAH DI KABUPATEN TRENGGALEK

terpenuhinya kebutuhan dasar hidup seharihari.

Menurut Parsudi Suparlan dalam Ibrahim (2007: 12) menjelaskan kemiskinan diartikan sebagai "... suatu standar tingkat hidup yang rendah, yaitu adanya suatu tingkat kekurangan materi pada sejumlah atau segolongan orang dibandingkan dengan standar kehidupan yang umum berlaku dalam masyarakat yang bersangkutan". Dari pengertian di atas dapat diketahui bahwa kemiskinan merupakan sesuatu yang relatif, artinya antara satu masyarakat dengan masyarakat lain memiliki permasalahan kemiskinan yang berbeda-beda yang diukur dari standar kehidupan yang berlaku secara umum.

Lembaga Manajemen Infaq dalam pemberdayaan ekonomi memiliki program dalam bidang ekonomi salah satunya yaitu dalam bidang berternak. Indonesia sebagai Negara agraris yang mayoritas masyarakatnya bertempat tinggal di daerah pedesaan merupakan salah satu faktor dalam pembangunan nasional. Pembangunan masyarakat pedesaan dapat terlaksana secara efektif apabila mampu meningkatkan kesejahteraan masyarakat desa secara berkesinambungan, sehingga masyarakat desa menjadi mandiri dalam arti dapat mengatasi berbagai masalah yang timbul dari dalam dan dapat meminimalisir berbagai dampak negatif yang timbul dari lvar. Pedesaan mempunyai potensi Sumber Daya yang tinggi khususnya di bidang peternakan, namun kurang digali secara maksimal sehingga belum mencapai sasaran utama yaitu kesejahteraan masyarakat.

Peternakan dibagi menjadi dua, sebagai berikut:

1. Peternakan Tradisional

Adalah usaha peternakan yang dilakukan secara sambilan untuk mencari tambahan penghasilan di luar pekerjaan utama. Pemeliharaan ternak dilakukan secara sederhana dan belum disesuaikan dengan aturan yang telah ditetapkan. Peternakan semacam ini mempunyai tingkat produksi yang relative rendah dan diusahakan sendiri oleh petani dan anggota sebagai usaha sambilan atau sampingan.

\section{Perusahaan Peternakan}

Adalah usaha peternakan yang di usahakan pada tempat-tempat tertentu, perkembang biakan dan manfaat peternakan diatur dan diawasi manusia. Merupakan usaha peternakan dalam skala besar, sehingga mempunyai tingkat produksi yang tinggi dan memerlukan tenafa kerja yang lebih banyak, serta memanfaatkan hasil mkemajuan ilmu pengetahuan dan teknologi dalam pengembangan usahanya. Dikemukakan bahwa beternak sapi atau kambing 
Wulanda, et al/Jurnal Ekonomi Syariah Teori dan Terapan Vol. 6 No. 8 Agustus 2019: 1690-1705; PERAN LMI DALAM PEMBERDAYAAN EKONOMI MASYARAKAT MISKIN MELALUI PROGRAM GADUH TERNAK BAROKAH DI KABUPATEN TRENGGALEK

mempunyai fungsi dan alasan yang mendorong usaha ternak sapi di daerah pedesaan. Sehingga memiliki fungsi sebagai berikut :

1. Sebagai usaha sampinganbagi petani dan masyarakat yang dapat memberikan tambahan pengahsilan

2. Bagi masyarakat Islam, ternak sapi juga dapat sebagai ternak korban selain domba dan kambing

3. Hewan ternak dapat melambangkan tingkat sosial seseorang dalam masyarakat, seseorang yang memiliki hewan ternak lebih banyak maka dimata masyarakat memiliki struktur sosial yang belih tinggi.

\section{METODE PENELITIAN}

Metode penelitian pada umumnya merupakan cara ilmiah untuk mendapatkan data dengan tujuan dan kegunaan tertentu. Aktivitas penelitian secara subtansi ditandai oleh empat hal, yaitu adanya upaya bersifat sistematik, adanya sesuatu hasil temuan, adanya manfaat dan adanya tindak lanjut penyebarluasan temuan (Mukhadis, 2013:70).

Penelitian yang dilakukan dalam penelitian ini melalui pendekatan kualitatif. Pendekatan kualitatif dengan menggunakan metode studi kasus deskriptif dengan desain khusus tunggal (single case) karena penelitian ini hanya meneliti satu kasus yaitu program Lembaga Manajemen Infaq Trenggalek.

Ruang lingkup penelitian Ruang lingkup penelitian ini hanya mencakup satu lembaga amil zakat saja, yaitu Lembaga Manajemen Infaq (LMI). Tema penelitian yang diangkat adalah meliputi peran program Gaduh Ternak Barokah, pemberdayaan dan masyarakat miskin yang disalurkan melalui program-program yang telah di rancang oleh Lembaga Manajemen Infaq (LMI). Penelitian ini juga membahas bagaimana peran melalui program tersebut dapat memberikan dampak bagi pemberdayaan ekonomi masyarakat miskin, khususnya di Kabupaten Trenggalek yang menjadi objek studi kasus.

Data yang digunakan dalam penelitian ini meliputi data primer dan data sekunder. mendefinisikan data primer adalah data yang didapat dari hasil wawancara dan observasi langsung dari lapangan dan data yang dihasilkan lebih banyak berwujud kata-kata dan tindakan dari objek penelitian. Data primer juga dapat disebut sebagai data asli. Untuk mendapatkan data primer, peneliti harus mengumpulkannya secara langsung. Dalam penelitian ini, yang menjadi sumber (key informan) dan (informan) adalah : 1. devisi pemberdayaan ekonomi 2. Penerima manfaat program pemberdayaan (peternak). 
Wulanda, et al/Jurnal Ekonomi Syariah Teori dan Terapan Vol. 6 No. 8 Agustus 2019: 1690-1705; PERAN LMI DALAM PEMBERDAYAAN EKONOMI MASYARAKAT MISKIN MELALUI PROGRAM GADUH TERNAK BAROKAH DI KABUPATEN TRENGGALEK

Prosedur pengumpulan data merupakan langkah yang paling strategis dalam penelitian, karena tujuan utama dari penelitian adalah mendapatkan data, tanpa mengetahui teknik pengumpulan data, maka peneliti tidak akan mendapatkan data yang memenuhi standar data yang ditetapkan, dalam penelitian ini penulis menggunakanteknik pengumpulan data sebagai berikut:

1. Persiapan Awal Peneliti mengurus surat ijin penelitian skripsi pada bagian akademik Fakultas Ekonomi dan Bisnis Universitas Airlangga sebagai pelengkap untuk ke tempat riset Lembaga Manajemen Infaq di Trenggalek.

2. Observasi Langsung dan Wawancara Peneliti melakukan observasi langsung pada pihak LMI Trenggalek. Peneliti melakukan observasi lapangan yang bertujuan untuk mengamati proses operasional lembaga yang fokusnya untuk memberdayakan ekonomi. Lalu peneliti menyiapkan pertanyaan yang akan diajukan kepada informan selanjutnya melakukan recording (merekam), mencatat semua data-data informasi yang sudah didapat.

3. Dokumentasi Hasil observasi dan wawancara dari objek penelitian akan didokumentasikan sendiri oleh peneliti.

4. Pengumpulan Data Peneliti mengumpulkan data primer yang diperoleh dari hasil wawancara dengan informan yang sudah dilakukan secara terbuka.

Teknik pengumpulan data dalam studi kasusu menurut Yin (2014) memilik enam cara yakni, dokumen, rekaman arsip, wawancara, observasi langsung, observasi partisipan, dan perangkat fisik. Pada penelitian ini juga menggunakan triangulasi sumber. Teknik ini memudahkan peneliti untuk memeriksa kredibilitas data tersebut. Karena dalam teknik ini untuk mendapatkan kebenaran yang mutlakdiperlukan berbagai metode dan sumber perolehan data yang beraneka ragam sehingga kredibilitas data yang didapatkan akan semakin kuat. Teknik keabsahan data penelitian.

\section{HASIL DAN PEMBAHASAN}

\section{Analisis Hasil Wawancara}

Hasil penelitian telah didapat melalui proses pengumpulan data yang dilakukan pada objek dan subjek penelitian. Pengumpulan data tersebut disesuaikan dengan indikator-indikator yang mengukur keberhasilan penerima manfaat sebagai pencapaian dari proses kesejahteraan yang dilakukan secara terus-menerus oleh Lembaga Manajemen Infaq. Indikator tersebut meliputi standar hidup material, aktivitas individu, kesehatan dan pendidikan. Perkembangan indikator kesejahteraan para informan dari hasil wawancara dan observasi adalah sebagai berikut: 
Wulanda, et al/Jurnal Ekonomi Syariah Teori dan Terapan Vol. 6 No. 8 Agustus 2019: 1690-1705; PERAN LMI DALAM PEMBERDAYAAN EKONOMI MASYARAKAT MISKIN MELALUI PROGRAM GADUH TERNAK BAROKAH DI KABUPATEN TRENGGALEK

\section{Informan 1}

\begin{tabular}{|l|l|l|l|}
\hline Indikator & $\begin{array}{l}\text { Sebelum bantuan } \\
\text { program LMI }\end{array}$ & $\begin{array}{l}\text { Sesudah } \\
\text { bergabung LMI }\end{array}$ & Keterangan \\
\hline $\begin{array}{l}\text { Standart hidup } \\
\text { material } \\
\text { (pendapatan) }\end{array}$ & $\begin{array}{l}\text { Kesulitan } \\
\text { (karena tidak ada } \\
\text { pekerjaan atau } \\
\text { pengangguran) }\end{array}$ & $\begin{array}{l}\text { Terbantu } \\
\text { (mendapat } \\
\text { pemberian modal } \\
\text { berupa kambing } \\
\text { ternak) }\end{array}$ & $\begin{array}{l}\text { Terbantu } \\
\text { (pendapatan } \\
\text { Meningkat) }\end{array}$ \\
\hline $\begin{array}{l}\text { Aktivitas individu } \\
\text { (pekerjaan) }\end{array}$ & PHK & $\begin{array}{l}\text { Penjual gorengan } \\
\text { dan berternak } \\
\text { kambing }\end{array}$ & $\begin{array}{l}\text { Terbantu } \\
\text { (Mempunyai } \\
\text { pekerjaan baru) }\end{array}$ \\
\hline Kesehatan & $\begin{array}{l}\text { Informan bisa mengakses dalam } \\
\text { bidang kesehatan baik bergabung } \\
\text { maupun tidak bergabung dengan LMI } \\
\text { karena LMI memiliki program } \\
\text { kesehatan keliling yang bisa diakses } \\
\text { oleh siapa saja }\end{array}$ & $\begin{array}{l}\text { Terpenuhi } \\
\text { (mendapat akses } \\
\text { pelayanan } \\
\text { kesehatan gratis } \\
\text { dari LMI) }\end{array}$ \\
\hline Pendidikan & $\begin{array}{l}\text { Terpenuhi dengan } \\
\text { adanya bantuan } \\
\text { program dari } \\
\text { pemerintah }\end{array}$ & $\begin{array}{l}\text { Terpenuhi dengan } \\
\text { adanya bantuan } \\
\text { program dari } \\
\text { pemerintah }\end{array}$ & Terpenuhi \\
\hline
\end{tabular}

\section{Informan 2}

\begin{tabular}{|l|l|l|l|}
\hline Indikator & $\begin{array}{l}\text { Sebelum bantuan } \\
\text { program LMI }\end{array}$ & $\begin{array}{l}\text { Sesudah bergabung } \\
\text { LMI }\end{array}$ & Keterangan \\
\hline $\begin{array}{l}\text { Standart hidup } \\
\text { material } \\
\text { (pendapatan) }\end{array}$ & $\begin{array}{l}\text { Kesulitan } \\
\text { (karena pendapatan } \\
\text { yang minim) }\end{array}$ & $\begin{array}{l}\text { Terbantu } \\
\text { (mendapat } \\
\text { pemberian modal } \\
\text { berupa kambing } \\
\text { ternak) }\end{array}$ & $\begin{array}{l}\text { Terbantu } \\
\text { (pendapatan } \\
\text { Meningkat) }\end{array}$ \\
\hline $\begin{array}{l}\text { Aktivitas individu } \\
\text { (pekerjaan) }\end{array}$ & Tukang bangunan & $\begin{array}{l}\text { Tukang bangunan, } \\
\text { membuka warung } \\
\text { dan berternak } \\
\text { kambing }\end{array}$ & $\begin{array}{l}\text { Terbantu } \\
\text { (Mempunyai } \\
\text { pekerjaan } \\
\text { tambahan) }\end{array}$ \\
\hline Kesehatan & $\begin{array}{l}\text { Informan bisa mengakses dalam } \\
\text { bidang kesehatan baik bergabung } \\
\text { maupun tidak bergabung dengan LMI } \\
\text { karena LMI memiliki program } \\
\text { kesehatan keliling yang bisa diakses } \\
\text { oleh siapa saja }\end{array}$ & $\begin{array}{l}\text { Terpenuhi } \\
\text { (mendapat akses) } \\
\text { pelayanan } \\
\text { kesehatan gratis } \\
\text { dari LMI) }\end{array}$ \\
\hline Pendidikan & $\begin{array}{l}\text { Terpenuhi dengan } \\
\text { adanya bantuan } \\
\text { program dari } \\
\text { pemerintah }\end{array}$ & $\begin{array}{l}\text { Terpenuhi dengan } \\
\text { adanya bantuan } \\
\text { program dari } \\
\text { pemerintah }\end{array}$ & Terpenuhi \\
\hline
\end{tabular}

\section{Informan 3}

\begin{tabular}{|l|l|l|l}
\hline Indikator & $\begin{array}{l}\text { Sebelum bantuan } \\
\text { program LMI }\end{array}$ & $\begin{array}{l}\text { Sesudah } \\
\text { bergabung LMI }\end{array}$ & Keterangan \\
\hline $\begin{array}{l}\text { Standart hidup } \\
\text { material } \\
\text { (pendapatan) }\end{array}$ & $\begin{array}{l}\text { Kesulitan } \\
\text { (karena } \\
\text { pendapatan yang } \\
\text { minim) }\end{array}$ & $\begin{array}{l}\text { Terbantu } \\
\text { (mendapat } \\
\text { pemberian modal } \\
\text { berupa kambing } \\
\text { ternak) }\end{array}$ & $\begin{array}{l}\text { Terbantu } \\
\text { (pendapatan } \\
\text { Meningkat) }\end{array}$ \\
\hline $\begin{array}{l}\text { Aktivitas individu } \\
\text { (pekerjaan) }\end{array}$ & Penjual sayur & $\begin{array}{l}\text { Penjual sayur, } \\
\text { penjahit dan } \\
\text { berternak } \\
\text { kambing }\end{array}$ & $\begin{array}{l}\text { Terbantu } \\
\text { (Mempunyai } \\
\text { pekerjaan } \\
\text { tambahan) }\end{array}$ \\
\hline Kesehatan & $\begin{array}{l}\text { Informan bisa mengakses dalam } \\
\text { bidang kesehatan baik bergabung } \\
\text { maupun tidak bergabung dengan } \\
\text { LMI karena LMI memiliki program } \\
\text { kesehatan keliling yang bisa diakses } \\
\text { oleh siapa saja }\end{array}$ & $\begin{array}{l}\text { Terpenuhi } \\
\text { (mendapat akses } \\
\text { pelayanan } \\
\text { kesehatan gratis } \\
\text { dari LMI) }\end{array}$ \\
\hline Pendidikan & $\begin{array}{l}\text { Terpenuhi dengan } \\
\text { adanya bantuan } \\
\text { program dari } \\
\text { pemerintah }\end{array}$ & $\begin{array}{l}\text { Terpenuhi dengan } \\
\text { adanya bantuan } \\
\text { program dari } \\
\text { pemerintah }\end{array}$ & Terpenuhi \\
\hline
\end{tabular}

\section{Informan 4}

\begin{tabular}{|l|l|l|l|}
\hline Indikator & $\begin{array}{l}\text { Sebelum bantuan } \\
\text { program LMI }\end{array}$ & $\begin{array}{l}\text { Sesudah } \\
\text { bergabung LMI }\end{array}$ & Keterangan \\
\hline $\begin{array}{l}\text { Standart hidup } \\
\text { material } \\
\text { (pendapatan) }\end{array}$ & $\begin{array}{l}\text { Kesulitan } \\
\text { (karena } \\
\text { pendapatan yang } \\
\text { minim) }\end{array}$ & $\begin{array}{l}\text { Terbantu } \\
\text { (mendapat } \\
\text { pemberian modal } \\
\text { berupa kambing } \\
\text { ternak) }\end{array}$ & $\begin{array}{l}\text { Terbantu } \\
\text { (pendapatan } \\
\text { Meningkat) }\end{array}$ \\
\hline $\begin{array}{l}\text { Aktivitas individu } \\
\text { (pekerjaan) }\end{array}$ & Tukang bangunan & $\begin{array}{l}\text { Tukang } \\
\text { bangunan dan } \\
\text { Berternak } \\
\text { kambing }\end{array}$ & $\begin{array}{l}\text { Terbantu } \\
\text { (Mempunyai } \\
\text { pekerjaan } \\
\text { tambahan) }\end{array}$ \\
\hline Kesehatan & $\begin{array}{l}\text { Informan bisa mengakses dalam } \\
\text { bidang kesehatan baik bergabung } \\
\text { maupun tidak bergabung dengan } \\
\text { LMI karena LMI memiliki program } \\
\text { kesehatan keliling yang bisa } \\
\text { diakses oleh siapa saja }\end{array}$ & $\begin{array}{l}\text { Terpenuhi } \\
\text { (mendapat akses } \\
\text { pelayanan } \\
\text { kesehatan gratis } \\
\text { dari LMI) }\end{array}$ \\
\hline Pendidikan & $\begin{array}{l}\text { Terpenuhi dengan } \\
\text { adanya bantuan } \\
\text { program dari } \\
\text { pemerintah }\end{array}$ & $\begin{array}{l}\text { Terpenuhi dengan } \\
\text { adanya bantuan } \\
\text { program dari } \\
\text { pemerintah }\end{array}$ & Terpenuhi \\
\hline
\end{tabular}

Indikator-indikator tersebut meliputi standart hidup materi, aktivitas individu, kesehatan dan pendidikan. Di bawah ini disampaikan hasil rangkuman intepretasi masing-masing indikator dalam proses pengumpulan data dengan informan sebagai berikut :

\section{Indikator Materi}

Dari hasil di atas diketahui bahwa hampir kelima informan yang sebagai sumber data adalah masyarakat yang mayoritas terkena imbas dari pemutusan hubungan kerja. Hasil penelitian menunjukkan bahwa sebagian besar kelima informan sebelum mendapatkan bantuan program pemberdayaan ekonomi mengalami kesulitan keuangan dikarenakan mereka kehilangan penghasilan utama meskipun setelah terkena PHK mereka memiliki perkejaan tetapi dengan pendapatan yang minimum. Setelah mendapatkan bantuan program pemberdayaan ekonomi kelima informan mengalami peningkatan dalam indikator 
Wulanda, et al/Jurnal Ekonomi Syariah Teori dan Terapan Vol. 6 No. 8 Agustus 2019: 1690-1705; PERAN LMI DALAM PEMBERDAYAAN EKONOMI MASYARAKAT MISKIN MELALUI PROGRAM GADUH TERNAK BAROKAH DI KABUPATEN TRENGGALEK

materi dan bisa memenuhi kebutuhan pokok. Meskipun peningkatan tersebut tidak naik secara tajam, namun kelima informan merasakan adanya perubahan kondisi perekonomian keluarga menjadi lebih baik jika dibandingan dengan sebelumnya. Dengan demikian, pada indikator materi dapat disimpulkan bahwa kelima informan menerima manfaat dan berhasil sejahtera dari adanya program Gaduh Ternak Barokah dalam pemberdayaan ekonomi masyarakat miskin di Trenggalek.

\section{Indikator Aktivitas Individu}

Hasil penelitian menunjukkan bahwa dari kelima informan merasa terbantu setelah menerima bantuan program pemberdayaan ekonomi. Dari hasil di atas diketahui bahwa, kelima informan mendapatkan pekerjaan sebagai peternak dari modal yang diberikan oleh LMI berupa hewan kambing serta dari penghasilan menjual kambing informan dapat membuka usaha mikro yang dikelolah sendiri secara mandiri, dengan cara berwirausaha kecil-kecilan. Para informan juga selalu mendapat dampingan tiap bulannya dari pihak LMI dalam memantau proses berternak kambing sehingga kini bisa mempunyai pekerjaan lagi. Setelah mendapatkan bantuan program pemberdayaan mereka merasa terbantu dan mendapatkan pekerjaan yang layak dan mampu mencukupi kebutuhan pokok sehari-harinya. Dengan demikian, pada indikator aktivitas individu dapat disimpulkan bahwa semua informan menerima manfaat dan berhasil sejahtera dari adanya program Gaduh Ternak Barokah dalam pemberdayaan ekonomi masyarakat miskin dari Lembaga Manajemen Infaq Trenggalek.

\section{Indikator Kesehatan}

Hasil penelitian menunjukkan bahwa dari kelima informan bisa mendapatkan akses kesehatan dengan baik dan gratis dari Lembaga Manajemen Infaqdalam program kesehatan keliling yang bisa di akses oleh masyarakat luas juga. Dengan demikian, pada indikator kesehatan dapat disimpulkan bahwa semua penerima manfaat atau informan menerima manfaat dan berhasil sejahtera dari adanya program pemberdayaan ekonomi dari program Gaduh Ternak Barokah dalam pemberdayaan masyarakat miskin kabupaten Trenggalek.

\section{Indikator Pendidikan}

Hasil penelitian menunjukan bahwa dari kelima informan bisa mendapatkan atau memberikan pendidikan yang terbaik untuk putra dan putrinya karena biaya pendidikan yang ditanggung oleh pemerintah namun untuk pemenuhan kebutuhan sepeti seragam, alat tulis,sepatu dll, para informan menyatakan masih sanggup untuk memenuhi kebutuhan tersebut ketika informan di phk dan setelah menerima bantuan dari LMI informan 
Wulanda, et al/Jurnal Ekonomi Syariah Teori dan Terapan Vol. 6 No. 8 Agustus 2019: 1690-1705; PERAN LMI DALAM PEMBERDAYAAN EKONOMI MASYARAKAT MISKIN MELALUI PROGRAM GADUH TERNAK BAROKAH DI KABUPATEN TRENGGALEK

menyatakan dapat memenuhi kebutuhannya dengan baik dan dapat mendaftarkan anaknya kedalam bimbingan belajar. Dengan demikian, pada indikator kesehatan dapat disimpulkan bahwa semua penerima manfaat atau informan menerima dengan baik manfaat dan berhasil sejahtera dari adanya program Gaduh Ternak Barokah dalam pemberdayaan masyarakat miskin kabupaten Trenggalek.

\section{SIMPULAN DAN SARAN}

\section{Kesimpulan}

Berdasarkan analisis dan pembahasan yang telah dijelaskan dalam bab sebelumnya bahwa Lembaga Manajemen Infaq dalam program Gaduh Ternak Barokah sudah berperan dalam meningkatkan kesejahteraan para infoorman penerima manfaat dari program pemberdayaan ekonomi melalui dana bantuan zakat, infag dan sedekah. Bantuan dari program pemberdayaan ekonomi masyarakat miskin di Kabupaten Trenggalek membawa dampak positif bagi kehidupan sehari-hari keempat informan.

\section{Saran}

Berikut adalah beberapa saran yang diharapkan dalam penelitian ini, yaitu:

1. Lembaga Manajemen Infaq Trenggalek Pihak LMI melakukan rapat koordinasi dengan beberapa kantor cabang atau organisasi keagamaan islam setempat agar memudahkan masyarakat yang membutuhkan bantuan segera bisa mengakses bantuan dari program tersebut dengan cepat dan memberi pengasawan terhadap seluruh penerima bantuan, agar proses jalannya program bantuan dapat dijalankan dengan maksimal. LMI lebih selektif dan mempertimbangkan pemberian bantuan kepada para informan, serta lebih meyeluruh dalam penyaluran program-program yang ada di Lembaga Manajemen Infaq bagi masyarakat umum.

Masyarakat umum khususnya umat muslim lebih sadar untuk menyalurkan dana zakat, infaq dan shadaqah pada tempat-tempat yang terpercaya dalam penyalurannya seperti LMI, BAZNAS.

2. Bagi Peneliti Selanjutnya

Peneliti selanjutnya diharapkan dapat meneliti peran Lembaga Manajemen Infaq dengan cakupan wilayah yang lebih luas dan informan lebih banyak, sehingga nantinya akan menghasilkan temuan yang lebih spesifik dan empiris mengenai peran LMI yang tersebar di kabupaten Trenggalek untuk mengurangi kemiskinan melalui program pemberdayaan ekonomi masyarakat miskin yang tersebar di Trenggalek.

\section{DAFTAR PUSTAKA}

Al-Utsaimin, Muhammad Shalih. 2012. Ensiklopedi Zakat. Jakarta: Pustaka asSunnah 
Wulanda, et al/Jurnal Ekonomi Syariah Teori dan Terapan Vol. 6 No. 8 Agustus 2019: 1690-1705; PERAN LMI DALAM PEMBERDAYAAN EKONOMI MASYARAKAT MISKIN MELALUI PROGRAM GADUH TERNAK BAROKAH DI KABUPATEN TRENGGALEK

Ash-Shiddieqy, M Hasbi. 2012. Pedoman Zakat. Semarang: PT Pustaka Rizki Putra

Asnaini, Zakat Produktif dalam Perspektif Hukum Islam, (Yogyakarta: Pustaka Pelajar, 2008), h 50 .Zkat Produktif dalam Perspektif Hukum Islam, (Yogyakarta: Pustaka Pelajar, 2008), h 63

Badan Pusat Statistik. 2017. Profil Kemiskinan di Indonesia September 2013-2016. Berita Resmi Statistik, (Online), (http://bps.go.id/brs/view/id/1099

diakses tanggal 20 Mei 2019).

Badan Pusat Statistik. 2017. Jumlah

Penduduk Miskin, Persentase Penduduk Miskin dan Garis Kemiskinan di Jawa Timur 2013-2016. Kemiskinan, (Online), (http://www.bps.go.id/linkTabelStatis/vi ew/id/1494, diakses tanggal 28 Mei 2019).

Badan Pusat Statistik. 2017. Profil Kemiskinan di Trenggalek September 2016. Berita Resmi Statistik, (Online), (http://bps.go.id/Brs/view/id/1227, diakses tanggal 28 Mei 2019).

Gulo, W. 2002. Metodologi Penelitian. Jakarta: Penerbit PT. Grasindo.

Hadi, $\quad$ AgusPurbathin. 2004. KonsepPemberdayaan, Partisipasi dan Kelembagaan dalam Pembangunan. Yayasan

Agribisnis/Pusat Pengembangan Masyarakat Agrikarya (PPMA).
Hafidhuddin, Didin. 2004. Zakat Dalam Perekonomian Modern. Jakarta: Gema Insani

Hikmat, Harry.2010. Strategi Pemberdayaan Masyarakat. Bandung: Humaniora Utama Press

Kamus Besar Bahasa Indonesia Esidi 3. 2007. Departemen Pendidikan Nasional. Balai Pustaka

Miftah, A. A. 2008. Pembaharuan Zakat untuk Pengentasan Kemiskinan di Indonesia. Innovatio (Online), Vol. VII, No. 14, (http://iepistemology.net/v1/attachments/1137 inv7n14\%20Pembaharuan\%20Zakat2unt uk\%20Pengentasan\%20Kemiskinan\%20d ¡\%20Indonesia\%20\%20A.A.\%20Miftaf.pdf, diakses tanggal 27 Mei 2019).

Mahendrawaty, Nanih. 2001. Pembangunan Masyarakat Islam darildeologi, strategi, sampai Tradisi. Jakarta: Remaja Rosda Karya.

Moleong, Lexy J. 2001. Metodologi Penelitian Kualitatif. Edisi Revisi. Bandung: Remaja Rosda Karya. 2010. Metodologi Penelitian Kualitatif. Edisi Revisi. Bandung: Remaja Rosda Karya.

Permana, Trisna Setia. 2016. Peran Pertanian Urban pada Kesejahteraan Petani Muslim Ditinjau dari Perspektif Islam (Studi pada Empat Kelompok Tani di Surabaya). Skripsi tidak diterbitkan. 
Wulanda, et al/Jurnal Ekonomi Syariah Teori dan Terapan Vol. 6 No. 8 Agustus 2019: 1690-1705; PERAN LMI DALAM PEMBERDAYAAN EKONOMI MASYARAKAT MISKIN MELALUI PROGRAM GADUH TERNAK BAROKAH DI KABUPATEN TRENGGALEK

Surabaya Ekonomi dan Bisnis Universitas

Airlangga.

Qardawi, Yusuf. 2011. Hukum Zakat. Bogor:

Pustaka Litera AntarNusa

Balai Pustaka

Qardhani, Yusuf. 2006. Kiat Islam Mengentaskan Kemiskinan. Jakarta: Gemalnsani Pers.

Ryandono, Muhammad Nafik Hadi. 2008. Ekonomi ZISWAQ (Zakat, Infaq, Shadaqah, dan Waqaf). Surabaya: Ifdi dan Cenforis.

Sabiq, Sayyid. 2008. Fikih Sunnah.. Jakarta:

Cakrawala Publishing

Soekanto, soerjono, Sosiologi Suatu Pengantar, Jakarta; Mizan

Somantri, Gumilar Rusliwa. 2005. Memahami Metode Kualitatif. Makara, Sosial Humaniora, Vol. 9 No. 2, Desember 2005: 57-65. Depok: Universitas Indonesia.

Sudibyo, Bambang. 1998. Kemiskinan di Indonesia. Bandung :Mirzan.
Sugiyono. 2009. Memahami Penelitian Kualitatif. Bandung: Alfabeta.

Sulistiani, AmbarTeguh. 2004. Kemitraan Dan Model-model Pemberdayaan. Jogjakarta: Gava Media.

Sumodiningrat, Gunawan. 1999. PemberdayaanMasyarakat Dan JPS. Jakarta: Gramedia.

Republik Indonesia. Undang-Undang RI Nomor 23 Tahun 2011 tentang Pengelolaan Zakat (Diakses dari http://dki.kemenag.go.id/index.php?a= artikel\&id $=14625 \& t=2646$ tanggal 27 Juni 2019).

Yin, Robert K.2012.Studi Kasus:Desain dan Metode. Jakarta: PT Raja Grafindo Persada.

Yulizar D. danMoch.Tufik. 2016. Fiqih Tamkin (Fiqih Pemberdayaan) :Membangun Modal Sosial Dalam Mewujudkan Khairu Ummah. Jakarta. Qisthi Press. Zuhayly, Wahbah Al. 2008. Zakat Kajian Berbagai Mazhab. Bandung: PT Remaja Rosdakarya. 